Красинский Владислав Вячеславович, кандидат юридических наук

Источник публикации: Красинский В.В. Качество российских законов // Право и политика, 2005. № 5. С. 96-104; www.krasinskiy.ru

\title{
КАЧЕСТВО РОССИЙСКИХ ЗАКОНОВ
}

В отечественной юридической литературе законотворчеству уделяется большое внимание ${ }^{1}$. Однако следует отметить, что имеющиеся исследования в основном охватывают два направления: изучение законодательной техники и тенденций развития современного законодательства. Вместе с тем при таком подходе в стороне остаются социологические аспекты законотворчества: выявление и учет при разработке законов многообразных интересов социально-политических общностей (классов, социальных групп, наций), исследования потребностей общества в нормативном регулировании и оценка населением принимаемых законов. В настоящей статье предлагаются некоторые критерии оценки результатов законотворчества.

С точки зрения социальной оценки законодательных актов можно условно выделить демократичные (недемократичные), качественные (некачественные), справедливые (несправедливые) и реальные (фиктивные) законы.

Главным критерием демократичности законов служит полнота выражения воли народа, проявляющаяся, в том числе посредством широкого участия населения (общественных организаций) в законотворчестве (как на стадии подготовки законопроектов, так и при их обсуждении и принятии) $)^{2}$. Законы, которые принимаются без участия населения и вопреки воле народа,

${ }_{1}^{1}$ См.: Поленина C.B. Теоретические проблемы системы советского законодательства. М., 1979; Поленина С.В. Законотворчество в Российской Федерации. М., 1996; Керимов Д.А. Законодательная техника. М., 1998; Бойко Л.М. теоретические проблемы законодательной техники: Проблемы совершенствования современного законодательства. М., 1997; Сенякин И.Н. Специализация и унификация российского законодательства. Проблемы теории и практики. Саратов, 1993; Язык закона / Под ред. А.С. Пиголкина. М., 1990 и др. 
являются недемократичными. Среди недемократичных законов следует особо выделить так называемые «конъюнктурные» законы, принятые в конкретной общественно-политической обстановке в стране в интересах отдельных политических сил, финансово-промышленных групп и криминальных структур.

Справедливость законов проявляется в том, что они позволяют учитывать интересы большинства членов данного общества, осуществлять сбалансированное распределение благ между различными социальными группами, устанавливают формальное равенство субъектов права. Справедливым может быть только демократичный закон.

Классифицирующими признаками качества законов являются выполнение возложенной на законы роли социальных регуляторов, принятие с соблюдением установленных процедур в пределах предметов ведения, соответствие Конституции и другим законодательным актам, проработанность юридической техники ${ }^{3}$.

Реальность законов заключается в их соответствии объективным закономерностям общественного развития. Реальность гарантирована конкретными материальными средствами и ресурсным обеспечением, в то время как фиктивные акты ничем не подкреплены и заведомо неисполнимы.

При сопоставлении предложенных критериев важно иметь в виду, что демократичный и справедливый закон может быть некачественным и фиктивным, в то время как конъюнктурный и несправедливый закон может быть весьма качественным и реальным.

Проанализируем особенности выделенных критериев законодательных актов.

В первую очередь рассмотрим проблему демократизма принимаемых законов.

2 Другие критерии названы ниже.

3 См. также: Зенков B.H. Учиться делать качественные законы / Выступление на семинаре «Правила подготовки проектов законов» // Журнал рос. права. 1998. № 8. С. 155 160; Качество закона и эффективность законодательства. М., 1993. 
Как представляется, демократизм законов находит свое проявление в следующих признаках:

- законы выражают волю многонационального народа Российской Федерации;

- законы затрагивают интересы большинства членов общества;

- распространяют свою юридическую силу на всех членов общества.

В отличие от демократичных законов, недемократичные законодательные акты не просто слабо отражают интересы населения, но зачастую и полностью противоречат им. Приведем несколько примеров.

Избранные народом депутаты Государственной Думы закрепляют в законодательстве широкий перечень собственных привилегий и гарантий деятельности, принимают выгодные только для них законы, основанные на изъятиях из общих нормативных установлений ${ }^{4}$. (В частности, почему замену депутатских льгот на денежные выплаты Федеральное Собрание будет рассматривать отдельным законом? Почему для депутатов Государственной Думы, членов Совета Федерации и ряда выборных лиц существуют иммунитеты от уголовного судопроизводства?) Вразумительного ответа нет.

Характерными являются и другие примеры.

Так, в последние годы особую остроту приобрели вопросы захоронения промышленных отходов. Ситуация усугубилась тем, что токсичные отходы стали «импортироваться» в Россию из развитых стран.

С 20 по 24 октября 2000 года в избирательные комиссии 62 субъектов Российской Федерации было сдано более 2, 5 млн. подписей россиян, высказавшихся за проведение референдума по вопросу о запрещении ввоза и захоронения на территории России радиоактивных отходов из-за границы.

\footnotetext{
${ }^{4}$ См.: Федеральный закон от 5 июля 1999 г. № 133-Ф3 (с изм. от 4 августа 2001 г.) «О статусе члена Совета Федерации и статусе депутата Государственной Думы Федерального Собрания Российской Федерации»; главу 52 Уголовно-процессуального кодекса Российской Федерации.
} 
Инициаторами проведения референдума выступили российские региональные природоохранные организации ${ }^{5}$.

Вместе с тем 21 декабря 2000 года в первом чтении (а впоследствии и окончательно) были приняты три законодательных акта, легализующих ввоз в Россию отработанного ядерного топлива: «О внесении дополнений в Федеральный закон «Об охране окружающей среды», «О внесении изменений и дополнений в Федеральный закон от 21 ноября 1995 г. № 170Ф3 «Об использовании атомной энергии», «О специальных экологических программах реабилитации радиационно-загрязненных участков территории».

Данными законами были предусмотрены приоритетность возврата радиоактивных веществ и изделий на их основе в государство-поставщика, обязательная государственная экологическая экспертиза внешнеторговых сделок на ввоз облученных сборок в Россию, а также лимиты на ежегодно ввозимые в Российскую Федерацию тепловыделяющие сборки ядерных реакторов. Однако принятые в России законы можно легально обойти в соответствующих подзаконных нормативных и ненормативных актах, закрепляющих несколько иные положения. Так, например, пункт «г» части 11 Положения о ввозе в Российскую Федерацию облученных тепловыделяющих сборок ядерных реакторов, утвержденного постановлением Правительства Российской Федерации от 11 июля 2003 г. № 418 определяет, что «внешнеторговый контракт на ввоз облученных сборок зарубежного производства должен предусматривать условия последующего возврата радиоактивных отходов в государство-поставщика, если иное не предусмотрено международными договорами Российской Федерации». А если предусмотрено? Примером именно такого договора может служить контракт о приеме отработавшего ядерного топлива венгерской АЭС «Панш» без последующего возврата радиоактивных отходов и продуктов переработки 266.

${ }^{5}$ См.: Защита прав человека. Сб. документов. 1998-2000. М.: Юрид. лит-ра, 2001. С. 
в Венгрию, который был признан недействительным Решением Верховного Суда Российской Федерации от 26 февраля 2002 года № ГКПИ 2001-16606.

Любопытно, что за внешне безобидным названием «специальные экологические программы реабилитации радиационно-загрязненных участков территории» также стоят внешнеторговые операции с облученными тепловыделяющими сборками ядерных реакторов ${ }^{7}$.

Следующий пример связан с проводимой руководством страны политикой т.н. «непопулярных решений», в основе которой лежит сокращение государственного финансирования социальной сферы за счет переноса на население соответствующих расходов. С этой целью рассмотрим историю появления законодательства о замене льгот на денежные выплаты.

12 апреля 2000 г. в первом чтении был принят проект Федерального закона «Об изменении, приостановлении действия и признании утратившими силу некоторых законодательных актов Российской Федерации в связи с Федеральным законом «О федеральном бюджете на 2000 год». Законопроект предусматривал отмену или приостановление действия ряда льгот, установленных для ветеранов, пенсионеров, инвалидов вследствие чернобыльской и иных радиационных аварий и общего заболевания, лиц, подвергшихся воздействию радиации, жертв политических репрессий, граждан, работающих и проработавших в районах Крайнего Севера и приравненных к ним местностях, лиц, обучающихся в государственных и муниципальных образовательных учреждениях, и иных граждан.

В своем обращении от 30 июня 2000 г. к депутатам Государственной Думы Федерального Собрания Российской Федерации Уполномоченный по правам человека в Российской Федерации отметил: «...полагаю, что изыскание Правительством Российской Федерации дополнительных средств путем сокращения определенных льгот и социальных выплат,

${ }^{6}$ См. Распоряжение Правительства Российской Федерации от 15 октября 1998 года № 1483-p «О приеме на переработку ограниченного количества отработавшего ядерного топлива из Венгерской Республики» // СЗ РФ. 1998. № 42. Ст. 5197. 
предусмотренных действующим законодательством, указанным категориям граждан (преимущественно из мало - и среднеобеспеченных слоев общества) и тем самым разрешить финансово-экономические проблемы за счет отказа от предоставления льгот этим гражданам недопустимо. Затрагивая основополагающие правовые гарантии в социальной сфере, данный законопроект существенно ущемляет и ухудшает социально-экономические права граждан и тем самым противоречит статье 55 (ч.2) Конституции Российской Федерации, согласно которой не должны издаваться законы, отменяющие или умаляющие права человека и гражданина» ${ }^{8}$.

Очередная попытка была предпринята в 2001-2002 гг. Федеральным законом от 7 мая 2002 года N 49-Ф3 "О внесении изменений и дополнений в некоторые законодательные акты Российской Федерации по вопросам денежного довольствия военнослужащих и предоставления им отдельных льгот" были внесены изменения в Федеральный закон от 27 мая 1998 года N 76-Ф3 "О статусе военнослужащих", отменяющие льготы, предоставленные военнослужащим, членам их семей, а также членам семей военнослужащих, погибших (умерших) в период прохождения военной службы, и членам семей граждан, проходивших военную службу по контракту и погибших (умерших) после увольнения с военной службы по достижении ими предельного возраста пребывания на военной службе, состоянию здоровья или в связи с организационно-штатными мероприятиями, имевших общую продолжительность военной службы 20 лет и более.

Взамен льгот указанной категории граждан была установлена ежемесячная 50-процентная денежная компенсация расходов по оплате жилой площади, коммунальных услуг, установки квартирных телефонов, абонентской плате за пользование телефонами, радиотрансляционными точками и коллективными телевизионными антеннами. Порядок выплаты

7 См. статью 1 Федерального закона от 10 июля 2001 г. № 92-Ф3 «О специальных экологических программах реабилитации радиационно-загрязненных участков территории» // Рос. газ. 2001. 13 июля. 612.

${ }^{8}$ См.: Защита прав человека. Сб. документов. 1998-2000. М.: Юрид. лит-ра, 2001. С. 
денежных компенсаций, в соответствии с законом, должно было определять Правительство Российской Федерации.

Однако Правительством Российской Федерации не определен порядок выплаты указанных денежных компенсаций, в связи с чем они гражданам не выплачиваются 9 .

Как свидетельствует история, новое - это хорошо забытое старое. Попытка, которая не удалась в 2000 г., успешно реализована масштабной монетизацией льгот с 1 января $2005 \Gamma^{10}$. При этом у миллионов граждан (например, военнослужащих, сотрудников правоохранительных органов) льготы отменены вообще без какой-либо компенсации ${ }^{11}$.

В рамках недемократичных законов рассмотрим так называемые «конъюнктурные» законы, принятые под влиянием определенной политической ситуации в угоду определенным лицам или социальным группам.

Чаще всего коньюнктурные законы являются следствием лоббизма, сущность которого заключается в финансировании и оказании различных услуг со стороны финансово-промышленных групп, а также криминальных структур конкретным представителям органов государственной власти и управления, отстаивающим интересы данных структур путем принятия определенных нормативных правовых актов, политических,

${ }^{9}$ См. Постановление Государственной Думы Федерального Собрания Российской Федерации от 15 ноября 2002 г. № 3299-III ГД «Парламентский запрос Председателю Правительства Российской Федерации М.М. Касьянову «О принятии мер по реализации статьи 24 Федерального закона от 27 мая 1998 г. № 76-Ф3 «О статусе военнослужащих» // СЗ РФ. 2002. № 48. Ст. 4755.

10 Отметим, что в качестве уловки юридической техники замена льгот на денежные выплаты установлена законом с удивительно непонятным названием, не имеющим непосредственного отношения к предмету регулирования. См. Федеральный закон от 22 августа 2004 г. № 122-Ф3 "О внесении изменений в законодательные акты Российской Федерации и признании утратившими силу некоторых законодательных актов Российской Федерации в связи с принятием Федеральных законов "О внесении изменений и дополнений в Федеральный закон "Об общих принципах организации законодательных (представительных) и исполнительных органов государственной власти субъектов Российской Федерации" и "Об общих принципах организации местного самоуправления в Российской Федерации" // Рос. газ. 2004. 31 августа.

11 В связи с изложенным у автора есть предложение: раз уж прослеживается стремление государства максимально освободиться от социальных расходов, то зачем лицемерить: давайте исключим из Конституции Российской Федерации положение о том, что Россия является социальным государством. 
административных и иных официальных решений ${ }^{12}$. Качественной характеристикой лоббизма является то, что продвижение интересов конкретных субъектов осуществляется за счет ущемления законных интересов других субъектов (различных категорий граждан, организаций, общества и государства в целом $)^{13}$.

Особой разновидностью коньюнктурных законов выступают законы, являющиеся политическим средством компромисса между различными социальными группами, в руках которых находится государственная власть. К числу таких относится Федеральный закон от 12 февраля 2001 года № 12Ф3 «О гарантиях Президенту Российской Федерации, прекратившему исполнение своих полномочий, и членам его семьи» ${ }^{14}$.

Статья 3 настоящего закона устанавливает неприкосновенность Президента России, прекратившего исполнение своих полномочий. Президент Российской Федерации, прекративший исполнение своих полномочий, не может быть привлечен к уголовной или административной ответственности за деяния, совершенные им в период исполнения полномочий Президента Российской Федерации, а также задержан, арестован, подвергнут обыску, допросу либо личному досмотру, если указанные действия осуществляются в ходе производства по делам, связанным с исполнением им полномочий Президента Российской Федерациии. Законом оговорена возможность лишения неприкосновенности Президента Российской Федерации, прекратившего исполнение своих полномочий, в случае возбуждения уголовного дела по факту совершения им тяжкого преступления. Вместе с тем предусмотрена особая процедура привлечения к

12 Лоббисты не только принимают нужные законы, но и «тормозят ненужные». Долгие годы российские парламентарии и должностные лица различного уровня успешно противостояли принятию Федерального закона «О борьбе с коррупцией». Когда же этот многострадальный закон, наконец, был принят, Президент Российской Федерации его не подписал.

${ }_{13}$ См.: Красинский В.В. Правовая оценка российского лоббизма // Юридический мир. 2004. № 8-9.C. 86.

${ }_{14}$ См.: Рос. газ. 2001. 15 февраля. В соответствии с данным законом было принято постановление Правительства Российской Федерации от 11 апреля 2001 года № 286 «Об обеспечении некоторых социальных гарантий Президенту Российской Федерации, прекратившему исполнение своих полномочий». Настоящий закон является одним из примеров копирования американского конституционного опыта. 
уголовной ответственности данного лица, которая предполагает представление Генерального прокурора Российской Федерации о лишении неприкосновенности и согласие обеих палат Федерального Собрания на лишение неприкосновенности. Решение Государственной Думы или Совета Федерации об отказе в лишении неприкосновенности Президента России, прекратившего исполнение своих полномочий, служит обстоятельством, исключающим производство по соответствующему уголовному делу и влекущим прекращение такого дела. Таким образом, факт исполнения обязанностей Президента Российской Федерации является основанием, освобождающим от юридической ответственности, что соответствует принципу «юридической безответственности монарха» в странах с монархической формой правления.

Другой особенностью закона является не вполне обоснованное наличие у Президента России, прекратившего исполнение своих полномочий, аппарата помощников Президента, финансируемого за счет средств федерального бюджета. Примечательно, что указанные помощники несут ответственность за исполнение своих обязанностей только перед бывшим Президентом, а не перед налогоплательщиками.

Примером политической коньюнктуры является федеральное избирательное законодательство. Характерным свойством данной подотрасли отечественного конституционного права выступает его обновление в интересах претендентов на выборные должности и депутатские мандаты перед каждой федеральной избирательной кампанией ${ }^{15}$.

15 Другими причинами трудно объяснить постоянные «эксперименты» с избирательными системами. См. Федеральный закон от 6 декабря 1994 года «Об основных гарантиях избирательных прав граждан Российской Федерации», Федеральный закон от 19 сентября 1997 г. «Об основных гарантиях избирательных прав и права на участие в референдуме граждан Российской Федерации», Федеральный закон от 30 марта 1999 г. (с изм. от 10 июля 2001 г.) «Об основных гарантиях избирательных прав и права на участие в референдуме граждан Российской Федерации», Федеральный закон от 12 июня 2002 г. (с изм. от 23 июня 2003 г.) «Об основных гарантиях избирательных прав и права на участие в референдуме граждан Российской Федерации»; Федеральный закон от 17 мая 1995 г. «О выборах Президента Российской Федерации», Федеральный закон от 31 декабря 1999 г. «О выборах Президента Российской Федерации», Федеральный закон от 10 января 2003 г. «О выборах Президента Российской Федерации»; Федеральный закон от 21 июня 1995 г. «О выборах депутатов Государственной Думы Федерального Собрания Российской Федерации», Федеральный закон от 24 июня 1999 г. (с изм. и доп. от 12 
Законодательство о выборах нельзя считать демократичным еще и в силу того, что оно нарушает принцип народного представительства, устанавливая низкий порог явки избирателей $(20 \%)^{16}$.

Большого внимания заслуживает проблема справедливости и несправедливости законов. Воплощение справедливости в законодательных актах возможно только в том случае, если вся правовая система государства служит интересам народа.

Нужно иметь в виду, что формальным признаком справедливости закона является устанавливаемое этим законом равенство субъектов права (применение равного масштаба субъективных прав, юридических обязанностей и ответственности).

Как это ни парадоксально, но даже высший юридический акт Российской Федерации - Конституция России 1993 г. не является вполне справедливым. Закон «О гражданстве» от 28 ноября 1991 г., отдельные положения которого вошли в Конституцию Российской Федерации, установил одновременно гражданство Российской Федерации и республик в составе Российской Федерации. Однако закрепленное Конституцией равноправие субъектов Федерации (ст.5) означает признание гражданства и других, помимо республик, субъектов Российской Федерации.

Сравнительно-правовой анализ ст. 5 и главы 3 Конституции содержит ряд коллизионных норм. С одной стороны, закрепляется равноправие субъектов Федерации во взаимоотношениях с федеральными органами государственной власти. С другой стороны, в ст. 64 наименования субъектов даны не общим списком, а в соответствии с фактической иерархией конституционно-правовых статусов: республики, края, области и т.д. В то же время существует т.н. «матрешечный феномен», нигде более в мире не встречающийся: вхождение ряда субъектов Российской Федерации

апреля 2001 г. и 10 июля 2001 г.) «О выборах депутатов Государственной Думы Федерального Собрания Российской Федерации», Федеральный закон от 20 декабря 2002 г. (с изм. от 23 июня 2003 г.) «О выборах депутатов Государственной Думы Федерального Собрания Российской Федерации» и др. 
(например, автономные округа) в состав другого, равноправного субъекта сложносоставного субъекта. В противоположность положениям ст. 5 Конституция предусматривает, что отношения автономных округов могут регулироваться федеральным законом и договором между органами государственной власти автономного образования и, соответственно, органами государственной власти края или области, что также противоречит принципу равноправия субъектов в составе Российской Федерации.

Не менее важной остается проблема качества законодательных актов. Так, в уголовно-процессуальном кодексе Российской Федерации почему-то отсутствуют задачи уголовного судопроизводства. В Кодекс Российской Федерации об административных правонарушениях знатоками юриспруденции введена статья 7. 27 «мелкое хищение». Что это за «гибрид» административного проступка и состава преступления? Попытка изобрести велосипед? Перечень примеров можно продолжить.

Как представляется, на качество принимаемых законов влияют следующие обстоятельства:

Во-первых, соблюдение законодательных процедур. По свидетельству юристов-практиков, временами законотворческий процесс Федерального Собрания доводился до абсурда: в один день принималось по 50-60 законов (особенно в последние дни парламентской сессии), в один день проходило по два или даже три чтения одного закона ${ }^{17}$. При такой лихорадочной работе неудивительно, что Президенту мог попасть на подпись не тот вариант закона, за который проголосовали депутаты ${ }^{18}$.

${ }^{16}$ См. п. 2 ст. 70 Федерального закона «Об основных гарантиях избирательных прав и права на участие в референдуме граждан Российской Федерации».

17 Ч. 1 и 8 ст. 119 раздела III Регламента Государственной Думы Федерального Собрания Российской Федерации от 22 января 1998 г. № 2134-II ГД (в ред. Постановления Государственной Думы Федерального Собрания Российской Федерации от 10 ноября 2004 г. № 1101-IV ГД) устанавливают возможность принятия закона без процедур второго и третьего чтений. Подобная норма облегчает возможность "протаскивания" выгодных лоббистам законов.

18 Cм.: Ivanov, Lev. Die Gesetzgebungstätigkeit der Föderalversammlung der Russländischen Föderation 1993-1995. Köln // Berichte des Bundesinstituts für ostwissenschaftliche und internationale Studien. Nr. 49-1996. 
Во-вторых, профессиональный уровень законодателя. Правовая грамотность депутатского корпуса имеет большое значение для качества и юридической техники издаваемых нормативных правовых актов ${ }^{19}$. Следует констатировать, что в последние годы знание законодателем правовых норм находится не на должном уровне ${ }^{20}$. Так, по данным бывшего руководителя Аппарата полномочных представителей Президента при Совете Федерации Иванова Л., в аппаратах комитетов Государственной Думы работает только $20 \%$ юристов, и лишь небольшая часть из них имеет законотворческий опыт. В аппаратах Федерального Собрания трудится категория лиц, имеющая весьма отдаленное отношение к законодательному процессу, которая рассматривает свое пребывание там в качестве привлекательного места для приобретения выгодных связей и трамплина для будущей карьеры.

В-третьих, добросовестность законодателей. В процессе подготовки и принятия законов в их текст отдельными юристами могут закладываться «юридические ловушки» (несоблюдение требований к форме и содержанию нормативного акта, противоречивые положения, неточная терминология, ошибки $)^{21}$. Подобные нормы позволяют заинтересованным сторонам использовать законодательные положения по собственному усмотрению, нередко в противоправных целя ${ }^{22}$.

В-четвертых, стабильность общественных отношений. В связи с тем, что законы воздействуют на общественные отношения, законодательное регулирование должно соответствовать общественному развитию; если же

75 .

19 См.: Шугрина Е.C. Техника юридического письма. М.: Изд-во Дело, 2001. С. 74-

${ }^{20}$ Серьезное деформирующее воздействие на систему российского законодательства оказала практика «указного законотворчества». В нарушение принципа отмены законодательного акта только принявшим его представительным органом власти указами Президента Российской Федерации изменялись или отменялись акты высшей юридической силы - законы. См. также: Лучин В.О. «Указное право» в России. М., 1996.

21 В 2000 г. Жириновский В.В. предлагал председателю Государственной Думы создать «отдел внутренней безопасности». Далее он отметил: «Комитет по собственности, Бунич выпускал законы, заменял. Мы принимаем закон, а он потом вставлял нужную фразу, вот так. Там же одно слово стоит заменить!». См. Стенограмма заседания Совета Государственной Думы от 22 июня 2000 г.

${ }_{22}$ Так, несовершенство действующего Федерального закона «О несостоятельности (банкротстве) предприятий» позволяет использовать процедуру банкротства в качестве инструмента передела собственности. 
общественные отношения нестабильны, то и законы будут недолговечными, носить приспособленческий характер.

Наконец, выделим группу законов, которые фактически законами не являются. Можно определить их как «квазизаконы», поскольку данные акты не содержат норм права, не регулируют общественные отношения и распространяются на конкретных индивидов.

В качестве примеров приведем Федеральные законы от 17 августа 1995 г. № 148-Ф3 "О жилищном, материальном обеспечении и медицинском обслуживании вдовы Н.М. Пятчица", от 28 декабря 1995 г. № 216-Ф3 "О жилищном, материальном обеспечении и медицинском обслуживании семьи С.А.Маркидонова", от 28 декабря 1995 г. № 219-Ф3 "О материальном обеспечении и медицинском обслуживании вдовы Д.А.Волкогонова", от 13 января 1996 г. № 11-Ф3 " О материальном обеспечении и медицинском обслуживании семьи В.В.Савицкого"23. В связи с прочтением данных "законодательных актов" возникают, по крайней мере, два вопроса.

Первый. Чем была вызвана необходимость принятия целого Федерального закона в отношении отдельного лица? Сегодня даже первокурсники юридических вузов знают, чем отличаются индивидуальные правовые акты от нормативных, и обстоятельства, которые обусловливают необходимость их принятия. Очевидно, для «отцов-законодателей» это осталось «тайной за семью печатями».

Второй. Чем народный избранник отличается от военнослужащих, сотрудников правоохранительных органов, которые погибли и продолжают гибнуть в Чеченской Республике? Почему государство не принимает тысячи таких законов и не устанавливает особых гарантий семьям погибших?

Несколько слов о реальности и фиктивности законов.

Как уже отмечалось выше, реальность законодательного акта должна рассматриваться в двух аспектах: как соответствие закона объективно января.

23 См.: СЗ РФ. 1995. № 34. Ст. 3427; Рос. газ. 1996. 16 января; Рос. газ. 1996. 18 
существующим условиям общественной жизни и как материально-ресурсная гарантированность действия принятого закона.

Большое практическое значение имеет гарантированность законов конкретными материальными средствами и ресурсным обеспечением.

Несмотря на то, что Конституция (ч.3 ст. 104) предписывает, что законопроекты о введении или отмене налогов, освобождении от их уплаты, о выпуске государственных займов, об изменении финансовых обязательств государства, другие законопроекты, предусматривающие расходы, покрываемые за счет федерального бюджета, могут быть внесены только при наличии заключения Правительства Российской Федерации, в 1993 - 1995 гг. Государственная Дума обсудила 80\% таких законопроектов без заключения правительства ${ }^{24}$. Или, несмотря на заключение Правительства, констатирующее отсутствие бюджетных средств для финансирования закона, закон принимался. Поэтому президент был вынужден 15 раз отклонять законы, для реализации которых не было финансовых средств ${ }^{25}$.

Ситуация с финансовым обеспечением законов коренным образом не изменилась и в настоящее время. Как справедливо отмечает руководитель направления Экспертного совета по проблемам законодательного обеспечения национальной безопасности при Председателе Государственной Думы Федерального Собрания Российской Федерации Дамаскин О.В., «в ряде случаев принимаемые законы не носят характера законов прямого действия, страдают декларативностью. Многие законы, особенно в социальной сфере, представляют собой набор благих пожеланий и не содержат четкого описания механизмов реализации желаемого состояния, мер контроля и ответственности органов исполнительной власти» ${ }^{26}$.

24 См.: Schneider, Eberhard. Das politische System der Russischen Föderation. Westdeutscher Verlag, 2002. S.102

25 См.: Ivanov, Lev. Die Gesetzgebungstätigkeit der Föderalversammlung der Russländischen Föderation 1993-1995. Köln // Berichte des Bundesinstituts für ostwissenschaftliche und internationale Studien. Nr. 49-1996.

${ }^{26}$ См.: Дамаскин O.B. Национальная безопасность в условиях глобализации: угрозы и противодействие. СПб, 2003. С. 87. 
Так, в соответствии со статьей 40 Конституции Российской Федерации, статьей 8 Федерального закона «О дополнительных гарантиях по социальной защите детей-сирот и детей, оставшихся без попечения родителей» детямсиротам и детям, оставшимся без попечения родителей, которые не имеют закрепленных жилых помещений, они предоставляются органами исполнительной власти во внеочередном порядке. Вместе с тем предусмотренные законодательством Российской Федерации социальные гарантии предоставления этой категории граждан жилых помещений во внеочередном порядке во всех субъектах Российской Федерации (кроме г. Москвы) нарушаются ${ }^{27}$.

Законодательно установив гарантии предоставления жилья военнослужащим, сотрудникам органов внутренних дел, органов и учреждений уголовно-исполнительной системы, гражданам, уволенным с военной службы, государство не выполняет взятых на себя обязательств ${ }^{28}$.

В ряде случаев не выделяются даже предусмотренные федеральным бюджетом деньги (примером может служить Парламентский запрос Председателю Правительства Российской Федерации М.М. Касьянову «О выполнении Правительством Российской Федерации требований ч.3 ст. 135 Федерального закона от 30 декабря 2001 г. №194-Ф3 «О федеральном бюджете на 2002 год» в части установления новых должностных окладов и

27 См. Обращение Государственной Думы Федерального Собрания Российской Федерации к Председателю Правительства Российской Федерации М.М. Касьянову «О принятии неотложных мер по обеспечению конституционного права детей-сирот и детей, оставшихся без попечения родителей, на жилье» (принято Постановлением Государственной Думы Федерального Собрания Российской Федерации от 25 декабря 2002 Г. № 3518-III ГД) // С3 РФ. 2003. № 1. Ст. 113.

28 См. Обращение Государственной Думы Федерального Собрания Российской Федерации к Президенту Российской Федерации В.В. Путину и Председателю Правительства Российской Федерации М.M. Касьянову по вопросам реализации президентской программы «Государственные жилищные сертификаты» и выделения в 2004 г. финансовых средств на решение задачи обеспечения жильем военнослужащих, сотрудников органов внутренних дел, органов и учреждений уголовно-исполнительной системы, граждан, уволенных с военной службы, и членов их семей (принято Постановлением Государственной Думы Федерального Собрания Российской Федерации от 21 июня 2003 г. № 4279-III ГД) // С3 РФ. 2003. № 26. Ст. 2642. 
иных условий денежного довольствия сотрудникам органов внутренних дел Российской Федерации») ${ }^{29}$.

Проведенное исследование позволяет сделать вывод о том, что российские законы полностью или частично не удовлетворяют предложенным критериям оценки. C учетом необходимости совершенствования законодательного регулирования предлагаются следующие меры.

В рамках Правовых управлений аппаратов Государственной Думы и Совета Федерации Федерального Собрания представляется целесообразным создать структурное подразделение (ввести обязательные для посещения курсы) по повышению правовой грамотности депутатского корпуса.

Предложить законодательным органам, политическим партиям и общественным организациям использовать свои возможности для информирования населения о планах законопроектной работы, принимаемых законах и их социальных последствиях.

Установить ответственность за лоббистскую деятельность и дополнить Уголовный кодекс Российской Федерации статьей $286^{1}$ следующего содержания:

«Статья 286 . Лоббизм

1. Лоббизм - то есть деятельность по оказанию влияния на разработку и принятие органами государственной власти нормативных и иных правовых актов, административных, политических и иных решений в интересах конкретных клиентов, осуществляемая представителями органов государственной власти с использованием своих должностных полномочий, повлекшая за собой нарушение прав и законных интересов граждан или организаций либо охраняемых законом интересов общества или государства,

${ }^{29}$ См. Постановление Государственной Думы Федерального Собрания Российской Федерации от 24 апреля 2002 г. № 2693-III ГД// СЗ РФ. 2002. № 18. Ст. 1733. 
наказывается штрафом в размере от семисот до двух тысяч минимальных размеров оплаты труда и лишением права занимать определенные должности или заниматься определенной деятельностью на срок от трех до пяти лет, либо лишением свободы на срок до пяти лет;

2. То же деяние, совершенное:

а) организованной группой;

б) по заданию российских финансово-промышленных групп;

в) по заданию иностранных государств или организаций, наказывается лишением свободы на срок от десяти до пятнадцати лет». Ввести процедуру общественной экспертизы законодательных актов, которая бы включала криминологическую, социально-экономическую, лингвистическую и иную профессиональную оценку принимаемых законов. На федеральном уровне субъектами проведения общественной экспертизы законов могли бы стать Общественная Палата Российской Федерации и Уполномоченный по правам человека в Российской Федерации, на уровне субъектов Федерации - правозащитные организации, общественные объединения и профсоюзы. В случае отрицательного заключения общественной экспертизы законодательный акт возвращается в законодательный орган для устранения замечаний и доработки.

Установить минимальные сроки обсуждения законопроектов и исключить часть 8 ст. 119 раздела III Регламента Государственной Думы Федерального Собрания Российской Федерации, предусматривающую возможность принятия закона, минуя процедуры второго и третьего чтений. 